\title{
Politik og værdipolitik
}

\section{Redaktionen}

Som introduktion til dette temanummer om værdipolitik, kan du her læse to korte bud på, hvad forskellen mellem politik og værdipolitik er, fra repræsentanter fra tænketankene CEPOS og CEVEA. På en økonomisk højre- og venstreskala tilhører de to tænketanke hver deres fløj, men som det følgende illustrerer, er de måske reaktion på samme politiske tendens og derfor enige om, hvilken rolle værdipolitik bør spille i den politiske virkelighed? Tidsskriftet POLITIK har stillet Jens Jonathan Steen fra CEVEA og Henrik Gade Jensen fra CEPOS fire spørgsmål:

POLITIK: Hvordan vil du forklare baggrunden for oprettelsen af jeres tanketank?

Henrik Gade Jensen (HGJ): Opkomsten af tænketanke afspejler ideernes betydning i politik. Når den offentlige mening eller pressen kaldes den fjerde statsmagt, afspejler det vigtigheden af ideer, tanker og argumenter. Det var denne virkelighed, som statsminister Anders Fogh Rasmussen udtrykte i 2003 efter opgøret med smagsdommeriet: „Udfaldet af kulturkampen afgør Danmarks fremtid. Ikke den økonomiske politik. Ikke teknokratiske ændringer af lovgivningssystemer" (Weekendavisen 17/1 2003). Kulturkamp er kamp om hegemoni, dvs. kamp om at definere begreberne og præge ordene. Siden 1970erne følte mange borgerlige i Danmark, at de intellektuelt befandt sig i defensiven overfor venstrefløjen og kulturradikalismen. Statsminister Poul Schlüter kundgjorde i 1984, at ideologi var noget bras, og ønskede derfor ikke noget ideologisk opgør eller nogen kulturkamp. Flygtninge- og indvandrerpolitik blev heller ikke anset for et åbent politikfelt. Vigtigst for den borgerlige regering 1982-1993 var genopretning af økonomien.
Efter valget i 2001 og opkomsten af et VKO-flertal, blev der signaleret kulturkamp, manifesteret med nytårstalen mod smagsdommeriet. Men realpolitisk tog VK-regeringen ingen tilløb til opgør med den socialdemokratiske velfærdsstat. Denne situation gav en gunstig jordbund for en tænketank, der kunne råde bod på det politiske svigt, som $\mathrm{V}$ og K efter nogle borgerliges mening i Folketinget lagde op til. Der var behov for en kritisk funktion i offentligheden, som de borgerlige, regeringsbærende partier forsømte.

Jens Jonatan Steen (JJS): Vi har oplevet en dramatisk underprioritering af ideernes betydning i dansk politik i de senere år. Som den amerikanske professor i kognitiv lingvistik George Lakoff har sagt: „When you think you just lack words, what you really lack are ideas!“. Pointen er at centrum-venstre har glimret ved deres fravær i en række vigtige politiske diskussioner om verdens beskaffenhed, som netop tager udgangspunkt i de ideer og værdier, som politikken formuleres ud fra. Det betyder også, at DF's succes ikke bare er et udtryk for egne evner, men ligeledes repræsenterer manglende evner hos de øvrige partier.Der har været to tendenser: Dels det at man ifølge lektor Torben Bech Dyrberg har kaldt for en moderne venstreorientering, der har spillet på multikulturalisme, politisk korrekthed og offermentalitet. Dels det som Anthony Giddens kalder for den tredje vej og „beyond left and right“. Det kan på dansk bedst oversættes til „hinsides højre/venstre“ eller måske endda "hinsides politik“ overhovedet. I det sidste tilfælde har man således ophøjet pragmatisme til sin højeste værdi, reduceret politik til administration, og som politiker reelt gjort sig selv overflødig. Og så er det nok ikke så mærkeligt, at man mister folkelig opbakning.

Det har betydet, at man på det politiske centrumvenstre har skubbet ideologierne og de politiske modsætninger i baggrunden - man har accepteret en stigende 
afideologisering. Venstrefløjen er som nævnt i stedet begyndt at efterstræbe konsensus, pragmatisme og en generel systemtænkning, som værdi- og ideologifrit skal indfri borgernes krav. Det betyder samtidig, at man giver et billede af, at der kan laves en distinktion mellem politik som sådan og værdipolitik. Man bruger værdi- og kulturkamp som parkeringsplads for de temaer, som endnu ikke lader sig pragmatisere.

\section{POLITIK: Hvordan forstår du relationen mellem begrebet politik og begrebet vardipolitik?}

JJS: Al politik er værdipolitik. Tingene hænger sammen: Værdipolitik kan ses som kampen om at definere et samfunds eller en befolknings værdier. Men da al politik er værdibaseret vil denne definering også påvirke de konkrete politiske prioriteter, der i en distinktions-optik opfattes som ikke-værdipolitiske. Så værdipolitikken er indirekte en integreret del af alle politiske beslutninger, mens disse beslutninger naturligvis også påvirker udviklingen og fastholdelsen af værdier.

Værdipolitik kan i denne optik ikke bare reduceres til kvinder med burka, reduktion af den kriminelle lavalder, nye regler for fiskeknive eller mange af de andre absurde tiltag, som ifølge den offentlige opinion betragtes som værdipolitik. Værdipolitik handler tværtimod om de grundlæggende samfundsværdier.

HGJ: Der er ingen modsætning mellem værdipolitik eller velfærds- og fordelingspolitik. Det er i allerhøjeste grad også værdipolitik at analysere en høj skatteprocents konsekvenser for arbejdsmarkedet, velstanden og civilsamfundet. Når et værdigrundlag består i et ønske om lavere skat, skyldes det en værdipolitisk eller normativ præmis om at opnå et stærkere samfund, hvor borgernes valg og præferencer slår mere direkte igennem ved produktion og fordeling af velfærdsydelser og kulturprodukter samt at staten eller det offentlige administrerer mindre end, hvad borgerne selv kan via markedet eller civilsamfundet.

Vi fører kulturkamp hver dag. Kulturkampen er en liberal kulturkamp, hvor det drejer sig om, at dansk kultur som udgangspunkt ikke skal dikteres politisk, men være et resultat af borgernes egne ønsker og valg. Derfor har vi som udgangspunkt heller ikke konkrete værdier at arbejde for, men tilstræber mere at fastholde og sikre den overordnede ramme om et frit og liberalt samfund. Man kunne måske kalde det meta-værdier, fordi de angiver rammebetingelser. Den vigtigste værdipolitiske prioritering er at fokusere på de overordnede rammer, som er nødvendige for at Danmark kan have et levedygtigt, velstandsproducerende og sammenhængende civilsamfund. Det er også værdipolitik at bidrage til at skabe en bedre integration, fordi der er store økonomiske omkostninger forbundet med så mange ledige i den arbejdsduelige alder. Her kommer værdier mere direkte ind, fordi der også her kan være tale om værdier, der blokerer for en integration i det danske samfund.

\section{POLITIK: Hvem fär noget ud af vardipolitik?}

JJS: Den såkaldte „værdipolitiske“ succesopskrift kan ses hos Dansk Folkeparti i Danmark og Fremskridtspartiet i Norge, der begge har taget afsæt i deres position som protestpartier. Ved at sætte en ny dagsorden har de formået at genskabe forbindelse til de oversete, i politisk henseende de tabte og utilfredse dele af de nationale befolkninger.

De spiller på følelser og identitet i form af den stigende trussel mod Danmark og dansk kultur. Det er tydeligt hvad, de kæmper for og imod. Og de formår at spille på en række kendte narrativer - de små mod de store, de svages forkæmper, den frække dreng i klassen som vi alle kender og forstår, og i et eller andet omfang kan identificere os med. Det gør værdipolitikken effektiv for dem.

Succesopskriften handler ifølge den nuværende og på mange måder komplet utilstrækkelige definition på værdipolitik om at udpege de områder, som det etablerede konsensus har glemt eller svigtet. Det muliggør en ofte følelsesladet dagorden, hvor man kan identificere sig med og imod nogle eller noget. Denne succes fungerer optimalt i et afpolitiseret miljø, som vi i stigende grad har oplevet de sidste 20 år i Danmark.

POLITIK: Hvordan forestiller du dig, at tanketanke kan spille en politisk rolle?

JJS: Fastholdelsen af en selvstændig værdipolitisk sfære betyder, at centrum-venstre i flere tilfælde ikke har fundet det nødvendigt at forholde sig til, hvad der er blevet set som personlige spørgsmål, og har kunnet fortsætte den ensidige fokus på den bureaukratiske systemtænkning. Men det har hverken betydet at værdierne eller ideologierne er forsvundet - blot at de er blevet overladt til andre, som vi bl.a. har set det under finanskrisen, der netop ikke alene har tekniske og strukturelle årsager, men også dybe ideologiske årsager. Derfor er dens håndtering også bestemt af ideologiske prioriteter, hvilket igen besvarer hvorfor ny regulering bliver mødt med hård ideologisk lobby. Til brug for at pege på nogle af disse dybereliggende årsager skal tænketanke spille en central rolle.

HGJ: Der er mange eksempler på, hvor stærke symboler kan være i offentligheden. Og hvor trængt rationaliteten kan være i en oppisket offentlighed. Ud fra en saglig betragtning er det ret vilkårligt, hvad der bliver kontro- 
versielle sager, og hvad der ikke vækker opsigt. Det viser, hvor stærke ideer og symboler er uanset deres karakter og rationelle grundlag. Derfor er det så vigtigt med uafhængige tænketanke, der ikke er forpligtet på popularitet og vælgeropbakning.

For tanker betyder langt mere end vi ofte tror. Det så John Maynard Keynes tydeligt for et par menneskealdre siden: „Økonomers og politiske filosoffers ideer er, både når de er forkerte og rigtige, mere magtfulde end det normalt antages. Faktisk regeres verden ikke af andet. Praktiske mænd, som tror de selv er helt uden nogen intellektuel indflydelse, er ofte slaver af en eller anden hedengangen økonom. Gale diktatorer, som hører stemmer i natten, destillerer deres vanvid fra nogle akademiske skriverier år tilbage ... Før eller senere er det ideer, ikke kapitalmagt, som er farlige på godt og ondt". 